\title{
ANIMASI INTERAKTIF SIMULASI TES BUTA WARNA DENGAN METODE ISHIHARA BERBASIS ADOBE FLASH CS 5
}

\author{
Deni Ambari \\ Program Studi Teknik Informatika \\ STMIK Nusa Mandiri Jakarta \\ Jl. Kramat Raya No 18 Jakarta Selatan \\ dennyambari@gmail.com \\ Fitri Latifah \\ Program Studi Komputerisasi Akuntansi \\ AMIK BSI Jakarta \\ Jalan Rs Fatmawati No 24 Pondok Labu Jakarta Selatan \\ fitri.flr@bsi.ac.id
}

\begin{abstract}
ABSTRAK
Buta warna adalah suatu kelainan yang disebabkan ketidakmampuan sel - sel kerucut mata untuk menangkap suatu spektrum warna tertentu akibat faktor genetik. Buta warna merupakan kelainan genetik/ bwaan yang diturunkan dari orang tua kepada anaknya, karena kelainan ini dibawa oleh kromosm $X$. Banyak masyarakat terlambat dalam mengetahui kebutaan warna yang dialaminya. Hal ini dikarenakan kurangnya informasi dan wawasan tentang tes buta warna. Oleh sebab itu aplikasi simulasi ini dibuat agar masyarakat dapat mengetahui tentnag macam - macam tes buta warna dan bisa dipelajari hasil dari tiap simulasi. Untuk membuat simulasi yang aktratif maka simulasi ini dibuat dengan adobe flash cs 5
\end{abstract}

Kata Kunci: Media Simulasi, Tes Buat Warna, Adobe flash cs 5

\section{ABSTRACTION}

Colour blindness isi disorder caused by the inability of teh eys cone cells to capture a spesific color spectrum due to genetic factors. Color blindness is a genetic disorder/ congenital inherited from parents to their childern, because this disorder is carried by the $X$ chomeosome. Many people find out too late in the color blindness. This isi due to lack of information and insight about the color blind test. Therefore, this aplication is made so that people can find out about all sort of color blindness test, the results of each simulation to make simulation aktratif silmulation is made with adobe cs 5

Keyword : Simulation, Color Blid Test, Adobe Flash cs 5

\section{PENDAHULUAN}

Melihat atau memandang suatu objek dengan penuh warna merupakan anugrah yang tidak ternilai harga nya yang diberikan Tuan Yang Maha Esa kepada makhluk ciptaan-Nya. Oleh karena itu kita harus senantiasa menyukuri dengan cara menjaga kesehatan mata kita. Namun kita juga menyadari bahwa tidak semua diberikan kesempurnaan mata untuk melihat sehingaa ada mengalami kecacatan atau kebutaan baik secara fisik dalam arti mengalami kebutaan total (netra) dan ada pula yang mengalmi cacat non fisik yang dikenal dengan istilah buta warna.

Menurut Santi (2011) Buta warna adalah kelainan yang disebabkan ketidakmampuan sel-sel kerucut dalam retina mata yang mengalami kelemahan atau kerusakan dan tidak mampu merespon warna dengan semenstinya. Buta warna merupakan kelainan genetik atau bawaan yang disebabkan yang ditutunkan dari orang tua kepada anaknya, kebutaan warna juga disebabkan seorang mengkonsumsi obat dalam periode waktu tertentu karena penyakit yang dideritanya. Untuk memastika seseorang mengalami buta warna tentunya harus memeriksakan diri kepada ahlinya yakni dokter spesialis mata namun dengan harga yang tentunya tidak murah untuk melakukan satu kali tes.

Masih banyak sebagian masyarakat beranggapan bahwa tes buta warna adalah tes yang sulit sehingga banyak yang engan untuk melakukannya.

\section{LANDASAN TEORI}

1. Pengertian Buta Warna

Buta warna adalah penyakit kelianan pada mata yang ditentukan oleh gen resesif pada kromosom seks, khususnya terpaut pada kromoson $X$ atau kondisi ketika sel - sel retina tidak mampu untuk merespon warna dengan semenstinya.

Maih banyak salah pengertian dengan istilah buta warna, karena sebenarnya penderita buta awarna itu pada tidak buta akan seluruh warna, karena penderia buta warna disebut dengan istilah gejala defisiensi daya melihat warna tertentu saja atau istilah disebut dengan colour vision deficiensy. 


\section{Klaifikasi Buta Warna}

Kesulitan yang dialami oleh penderia buta warna adalah kesulitan mengenali warna tertentu. Dalam tingkatannya buta warna dapat dikatagrikan sebabagai berikut :

a. Anomali Trikomat adalah suatu keadaan dimana tiga jenis sel kerucut tetap ada, tetapi satu diantaranya tidak normal atau tidak berfungsi daengan baik, sehingga penderita mengalami kesulitan untuk membedakan nuansa warna tertentu. Ada tiga jenis buta warna yang banyak dialami yaitu :

1. Protonomali (Lemah merah)

Adalah keadaan dimana sel kerucut warna merah tidak berfungsi dengan baik, sehingga penderita kurang sensitif untuk mengenali warna merah

2. Deuteranomali (Lemah Hijau)

Adalah keadan dimana sel kerucut warna hijau tidak berfungasi sengan baik sehingga penderia kurang sensitif untuk mengenali warna hijau

3. Tritanomali (Lemah Biru)

Adalah keadan dimana sel kerucut warna biru tidak berfungasi dengan baik sehingga penderia kurang sensitif untuk mengenali warna biru

b. Dikhorimat adalah keadaan dimana ketika satu dari tiga sel kerucut tidk ada. Ada tiga katagorii dikromasi yaitu :

1. Protonopia (buta warna merah)

Hal ini disebahkan sel krucut warna merah tidak ada yang mengakibatkan kecerahan warna merah atau perpaudannya berkurang

2. Deuteranopia ( buta warna hijau)

Hal ini disebabkan sel krucut warna hijau tidaka ada yang mengakibarkan kecerahan warna hijau atau perpaduannya berkurang.

3. Trianopia (buta warna biru)

Hal ini disebabkan karena sel krucut warna biru tidak ada yang mengakibatkan kecerahan warna biru berkurang

c. Monokhromat adalah kondisi retina mata yang mengalami kerusakan total dalam merespon warna, keadaan ini ditandai dengan berkurangnya semua penglihatan warna sehingga yang terlihat hanyalah warna putih dan hitam

\section{Metode Ishihara}

Tes kebuataan warna dengan metode Ishihara dikembangkan oleh $\mathrm{Dr}$ Shinobu Ishihara pada tahun1917, hingga saat ini metode ini menjadi salah satu pilihan utama hampir di semua negara untuk mengidentifikasi apakah seorang mengalami buta warna, tes ini di gunakan untuk mendeteksi gangguan peersepsi warna, berupa tabel warna khusus berupa lembaran pseudoisokkromatik (plate) yang disusun oleh titik-titik dengan kepadatan warna yang berbeda yang dapat dilihat dengan mata normal, tapi tidak bisa dilihat oleh mata yang mengami defisensi sebagai warna.

Alat tes Ishihara diakui dan banyak digunakan secara internasional debgai alat untuk penentuka gannguan kebutaan warna dan telah mengami penyempurnaan dan modifikasi dari waktu ke waktu alat Ishihara terbaru berisi 38 plat pada tahun 2009.

\section{METODOLOGI PENELITIAN}

\subsection{Desain Penelitian}

Dalam penelitian ini peneliti mendesain aplikasi dengan menggunakan model pembangunan sistem watel fall dengan langkah langkah sebagai berikut :

1. Analisa Kebutuhan Software

Pada langkah ini peneliti menganalisa kebutuhan software yang akan digunakan dalam perancangan aplikasi baik dari sistem operasi maupun software aplikasi dan juga kebutuhan software sesuai dengan kebutuhan pengguna pada saat aplikasi siap untuk di implementasikan

2. Desain

Desain merupakan fase awal yang terpenting dalam pembuatan sebuah aplikasi. Desain adalah membuat perencanaan secara rinci mengenai struktur aplikasi yang akan di bangun, gaya dalam kebutuhan bahan untuk aplikasi. Spesifikasi dibuat hendaknyacukup rinci sehingga pada tahapan berikutnya, yaitu tahap pengumpulan bahan dan pembuatan tidak dibutuhkan keputusan baru, melainkan menggunakan apa yang telah ditetapkan pada tahap desain. Namun demikian, sering terjadi penambahan atau pengurangan bahan, bahkan ada perubahan pada bagian aplikasi awal pengerjaan.

3. Code Generation

Code generation adalah proses yang menghasilkan kode atau pengkodean (coding) yang membuat kalimat-kalimat perintah menggunakan bahasa komputer. Di mana penulis harus mengikuti acuan baku yang tertera dalam bahasa pemprograman adobe flash cs 3, hingga terbentuk algoritma yang sesuai dengan yang penulis buat.

4. Testing

Testing dilakukan setelah tahap pembuatan dan seluruh bahan telah jadi atau telah selesai dibuat. Testing dilakukan untuk memastikan apakah hasilnya seperti yang diinginkan atau tidak? Aplikasi yang dilakukan harus dapat berjalan dengan baik di lingkungan pengguna, dimana pengguna dapat merasakannya adanya kemudahan dan manfaat dari aplikasi tersebut serta dapat menjalankannya.

5. Support

Berisikan perangkat yang akan digunakan dalam menunjang pembuatan suatu aplikasi.

\subsection{Pengumpulan data}

Untuk pengumpulan data pada penelitian ini peneliti menggunakan metode

1. Obervasi

Melakukan Observasi kepada narasumber baik kepada narasumber yang memahami tentang tes buta warna dan juga kepada nasasumber yang memahami aplikasi animasi. 


\section{Wawancara}

Mengali informasi langsung secara lisan kepada nasarasumber dan juga kepada user yang akan mengunakan aplikasi

3. Studi Pustaka

Melakukan tinjauan pustaka untuk mendapatkan informasi berupa data tulisan, keterangan melalui buku atau sumber referensi lainnya yang mendukung penelitian ini

\section{HASIL DAN PEMBAHASAN}

\subsection{Analisa Kebutuhan Software}

Dalam pebuatan aplikasi ini peneliti bermaksud untuk memberikan kemudahan dalam penggunaan, dimana pengguna hanya perlu melakukan input memlaui mouse saja.

Tahap selanjutnya adalah proses, kebutuhan apa saja yang diperlukan dalam pembuatan aplikasi, selanjutnya out put atau hasilnya adalah akan ada simulasi yang berbeda- beda dan akan ada soal yang berbeda-beda dengan tujuan untuk memberikan tantangan bagi pengguna.

\subsection{Desain}

Desain merupakan bagian penting dari suatu aplikasi. Untuk membuat struktur aplikasi dan gaya kebutuhan atau mengikuti tema dari pembuat atau klien. Berikut ini adalah bagian dari desain simulasi tes buta warna

a. Format

Program telah diformat dalam bentuk .exe sehingga tinggal mendoubel klik saja agar pengguna mudah dalam menggunakan aplikasi. Aplikasi yang dibuat menggambarkan tes warna tungga, tes ishihara dan tes warna turunan yang ditunjukan untuk pembelajran tingkat remaja dan dewasa.

b. Rule

Pada aplikasi ini pemain terleih dahulu memiliki tombol mainkan untuk memulai. Setelah permaian dimlai maka pemain akan di suguhkan dengan tiga jenis tes buta warna yang saling terkait dan pengguna akan mendapatkan nilai dan pembenaran ditiap pengguna simulasi tes buta warna

c. Policy

Dalam simulasi ini pengguna akan diberikan kesempatan mengubah apabila jawaban tidak memenuhi minimal nilai kebenaran yang dibutuhkan dari tiap simulasi

d. Scenario

Pengguna harus bisa menjawab soal dengan benar sesuai minimal kebenaran yang dibutuhkan dari simulasi agar dapat melanjutkan simulasi berikutnya

e. Event/Challenge

Pada aplikasi ini tantangan yang diberikan adalah pengguna harus berhasil menjawabn semua soal dengan tingkat yang semaikn sulit, jika berhasil menjawab soal dengan minimal nilai yang telah ditentukan maka akan lanjut ke simulasi berikutnya, jika tidak berhasl menjawab dengan minimal nilai yang telah ditentukan makan akan berhenti pada simulasi yang sedang dijalankan atau mengulangi simulasi. f. Roles

Peran pengguna harus dapat menjawab semua soal yang diberikan tentang simulasi tes buta warna dengan soal yang berubah ubah.

g. Decisions

Keputusan yang dapat dibuat pengguna dalam hal ini adalah menjawab soal sesuai urutan semulasi tes buta warna

h. Score Model

Pada core model nilai ditentukan dari soal yang telah dijawab dari tiap macam semulasi tes buta warna

i. Indication

Pada simulasi pertama apabila jawaban benar maka berganti ke soal berikutnya, apabila salah maka akan muncul jawaban pembenarannya. Pada simulasi kedua semua soal akan terus berganti baik benar ataupun salah dan jawaban pembenaran akan mncul bersamaan dengan nilai. Pada simulasi ketiga apabila jawaban benar makan soal berubah dan apabila salah maka sola tidak berubah atau melakukan pengulangan.

j. Symbol

Simbol yang digunakan berupa tombol-tombol diaman tiap tombol memiliki fungsi yang berbeda-beda sesuai deterangan yang tercantum pada tombol

\subsection{Perancangan Story Board}

Perancangan story board berisi tentang alur cerita dari aplikasi yang dibuat, berikut story board adalah

\section{a. Story Board Opening}

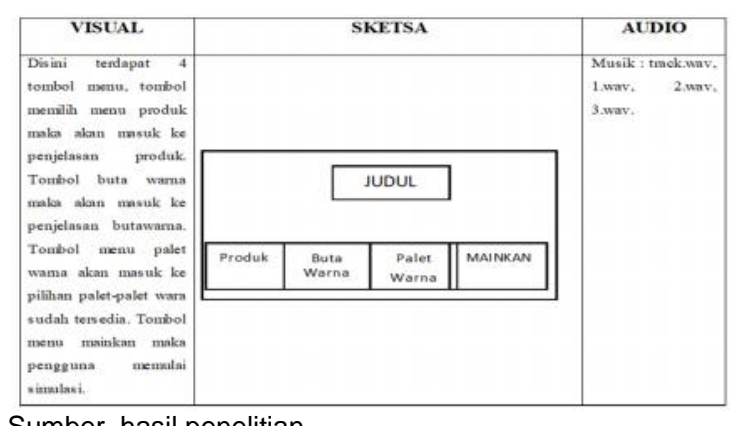

Sumber hasil penelitian

Gambar 3.1. Story Board Openning

b. Story Board Mainkan

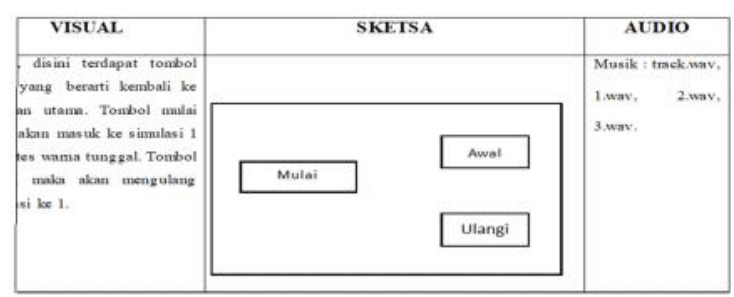

Sumber hasil penelitian

Gambar 3.2. Story Board Mainkan 
c. Story Board Tes Warna Tunggal

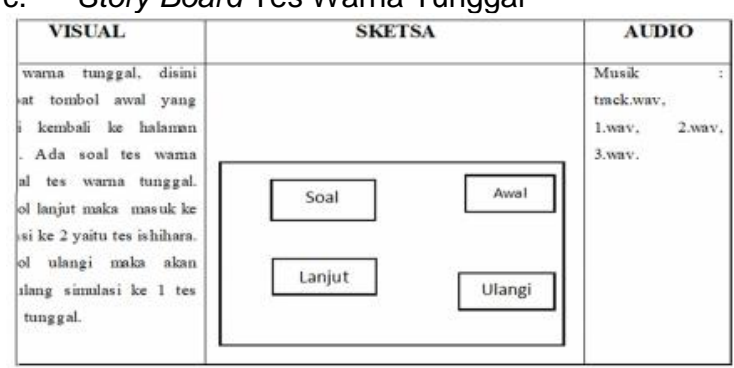

Sumber hasil penelitian

Gambar 3.3. Story Board tes Warna Tunggal

d. Story Board Tes Ishihara

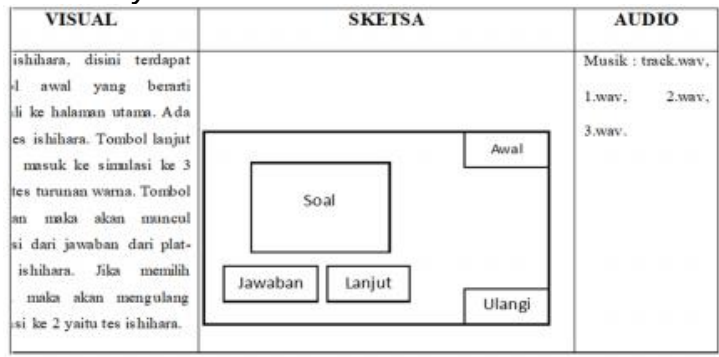

Sumber hasil penelitian

Gambar 3.4. Story Board tes Warna Tunggal

\section{e. Story Board Tes Turuana warna}

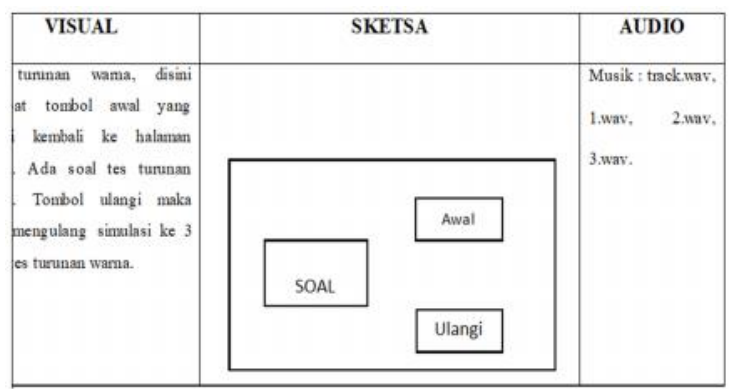

Sumber hasil penelitian

Gambar 3.5. Story Board tes turunan warna

\subsection{State Translation Diagram}

State transition diagram adalah suatu permodelan peraltan (modeling tool) yang menggamabrkan difat ketergantungan terhadap suatu sistem waktu nyata (real time system) dan tampilan tatap muka (interface) pada sistem skatif (on line). Pemodelan ini juga peneliti gunakan dalam menjelaskan alur - alur dari aplikasi yang peneliti rancang.

a. Scene Halaman Utama

Menggambarkan interaktif, pertama kali pengguna akan menemui opening. Setelah itu pengguna akan masuk ke halaman utama. Di dalam halaman utama terdapat beberapa pilihan diantaranya produk, buta warna, palet warna dan mainkan. Produk menjelaskan tentang pembuatan aimasi interaktif ini. Buta warna, pengertian butawarna dan metode tes buta warna. Palet warna berisi tentang palet palet warna. Miankan beiri tentnag simulasi tes buta warna.

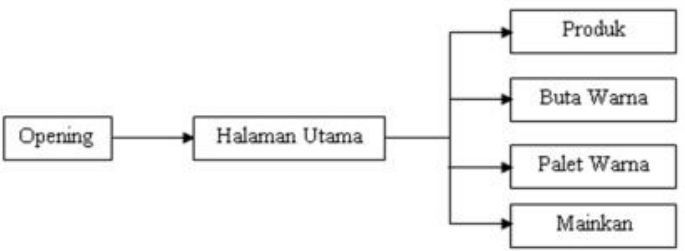

Sumber Hasil penelitian

Gambar 3.6. State Transition Diagram Halaman Utama

\section{b. Scene Mainkan}

Pada scene ini menggambarkan isi dari simulasi tes buta warna dengan jawaban dan tantnagan yang berbeda ditiap simulasi

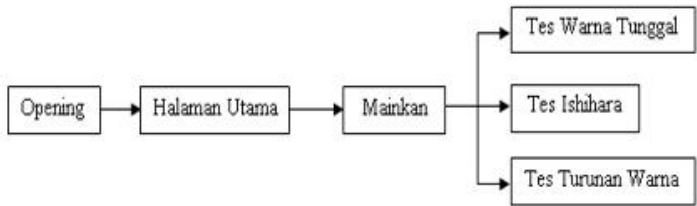

Sumber Hasil penelitian

Gambar 3.7. State Transition Diagram Mainkan

\section{c. Scene Tes Warna Tunggal}

Pada scene ini pengguna akan mendapatkan tes warna sebanyak 10 soal jika jawaban benar maka lanjut kesoal berikutnya dan jika salah maka akan menucul jawaban yang benar, setelah memenuhi minimal nilai kebenaran yang telah ditentukan makan akan lanjut ke tes beikutnya.

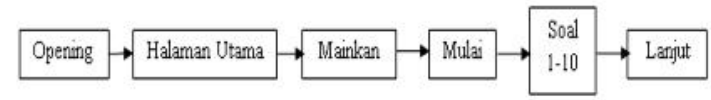

Sumber Hasil penelitian

\section{Gambar 3.8. Scene Tes Warna Tunggal}

\section{d. Scene Tes Ishihara}

Dalam scere ini pengguna akan mendapatkan tes ishiraha sebanyak 25 soal. Jika jawaban benar dan salah maka lanjut kesoal berikutnya. Jika memilih jawaban maka akan muncul angka yang tersembunyi dari plat-plat ishihara. Jika jawban benar maka lanjut beriktnya dan jika salah maka akan muncul jawaban yang benar. Setelah memenuhi nilai kebenaran yang telah ditentukan maka akan lanjut ke tes berikutnya.

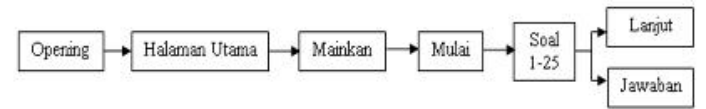

Sumber Hasil penelitian

Gambar 3.9. State Transition Diagram Tes Ishihara

e. Scene Tes Turunan Warna

Dalam scene ini pengguna akan mendapat tes turunan warna sebanyak 6 soal. Jika jawaban benar dan salah maka lanjut kesoal berikutnya. Jika jawaban benar maka lanjut kesoal berikutnya dan jika salah satu maka soal tidak akan berubah. Jika memilih ulang maka pengguna akan kembali 
melihat turunan warna sebelum mengulangi tes. Jika jawaban benar maka lanjut ke soal beritnya dan jika salah maka akan muncul jawaban yang benar. Setelah memenuhi minimal nilai kebenaran yang telah ditentukan maka tes selesai

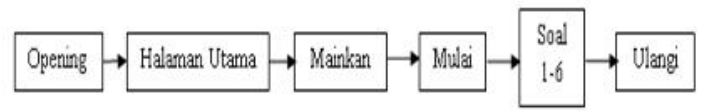

Sumber Hasil penelitian

Gambar 3.10.Scene Tes Turunan Warna

\subsection{Pengujian}

Setelah aplikasi di buat selenjutnya akan diuji dengan teknik pengujian perangkat lunak dengan dua cara yaitu

a. Pengujian White Box

Pengujian white box yang dilakukan guna memastikan bahwa aplikasi yang di bangun telah memenuhi ketentuan sebagai berikut :

1. Memberikan jaminan bahwa semua jalur independen pada suatu modul telah digunakan paling tidak 1 kali

2. Menggunakan semua keputusan logis pada sisi true dan false

3. Mengeksekusi semua loop (pengulangan).

4. Operasional pengguna aplikasi

Adapun hasil dari pengujian white box pada aplikasi yang dibuat sebagai berikut :

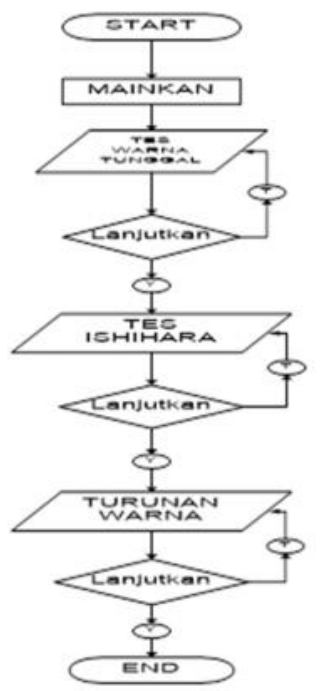

Sumber Hasil penelitian

Gambar 3.11. Bagan Alir pengujian

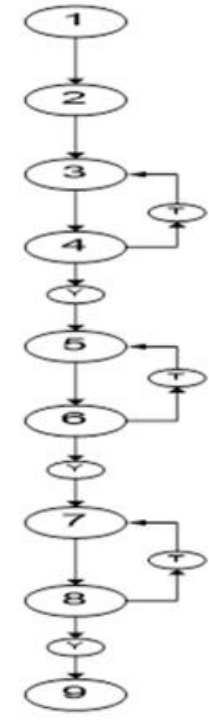

Sumber Hasil penelitian

Gambar 3.12. Bagan Grafik pengujian

Kompleksitas siklomatis (pengukuran terhadap kompleksitas logis suatu progam) dari grafik alir dapat diperoleh dengan rmus

$$
V(G)=E-N+2
$$

$E=$ Jumlah edge grafik alir yang ditandakan dengan anak panah

$\mathrm{N}=$ Jumlah simpul grafik alir yang ditandakan dengan gambar lingkaran

Sehingga kompliesitas siklomatisnya $\mathrm{V}(\mathrm{G})=11-9+2=4$

Sehingga baris set yang dihasilkan dari jalur independen adalah sebagai berikut :

1-2-3-4-5-6-7-8-9

1-2-3-4-3-4-5-6-7-8-9

$1-2-3-4-5-6-5-6-7-8-9$

$1-2-3-4-5-6-7-8-7-8-9$

b. Penujian Black Box

Pengujian white box yang dilakukan guna memastikan bahwa suatu event atau masukan akan menjalankan proses yang tepat dan menghasilkan output sesuai dengan rancangan yang dibuat 
Tabel 3.1. Pengujian Black Box

\begin{tabular}{|c|c|c|c|}
\hline INPUT /EVENT S & PROSES & $\begin{array}{l}\text { JUTPUTAE.KI } \\
\text { \$IAGE }\end{array}$ & $\begin{array}{c}\text { FASIL } \\
\text { PENG.J.AM }\end{array}$ \\
\hline $\begin{array}{l}\text { onbolmerujuhalaman } \\
\text { daria }\end{array}$ & 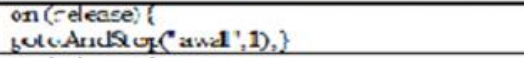 & $\begin{array}{l}\text { Nesam pilcan halaman } \\
\text { ulamid }\end{array}$ & Sesuai \\
\hline [onbolpsotnk & 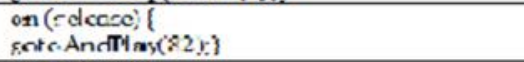 & $\begin{array}{l}\text { Meanor pil lon penjel acon } \\
\text { mentuk }\end{array}$ & Sesuai \\
\hline [ oxbol but a werna & $\begin{array}{l}\text { un (: elecse) ( } \\
\text { gotcindst of }(\$ 1) ; \text {; }\end{array}$ & 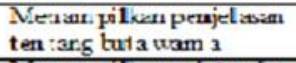 & Seazai \\
\hline $\begin{array}{l}\text { lonbol palet waraa } \\
\text { Imbolmainka }\end{array}$ & 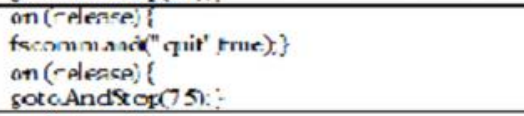 & $\begin{array}{l}\text { Neram pit kn palet nalet } \\
\text { sarna } \\
\text { Menar pilican awal } \\
\text { pernainan }\end{array}$ & $\begin{array}{l}\text { Sesuai } \\
\text { Sequai }\end{array}$ \\
\hline romboit res warn arimed & 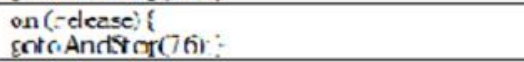 & $\begin{array}{l}\text { Nemulait es wam a } \\
\text { tun JgA }\end{array}$ & Searai \\
\hline [ustoolusishih as & $\begin{array}{l}\text { on (-Please) \& } \\
\text { sotc Andstor }(77)_{i} \text { : }\end{array}$ & Merudeit esishith all & Suseri \\
\hline $\begin{array}{l}\text { [onbol turnar wara } \\
\text { [asbolkenbali ken a u }\end{array}$ & 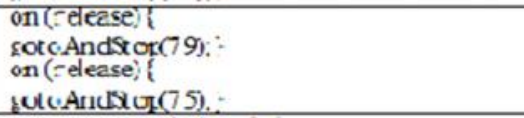 & $\begin{array}{l}\text { Menuai tes turuna } \\
\text { Maraa } \\
\text { Mesam pilican menu } \\
\text { ulamia }\end{array}$ & $\begin{array}{l}\text { Sesuai } \\
\text { Segai }\end{array}$ \\
\hline [onbolkx ksi & 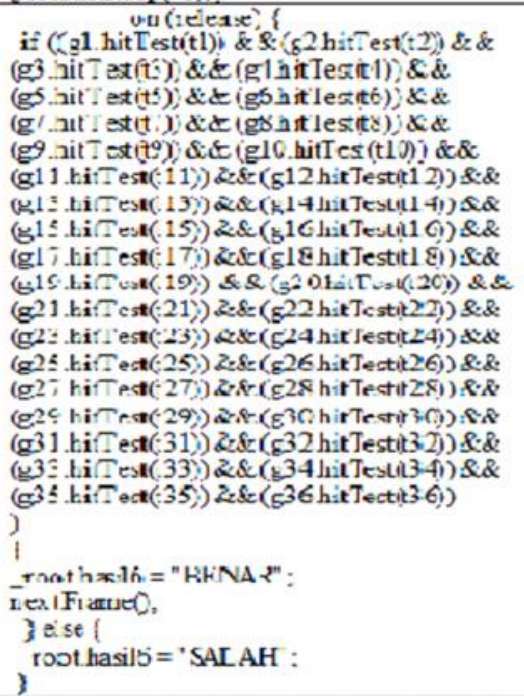 & 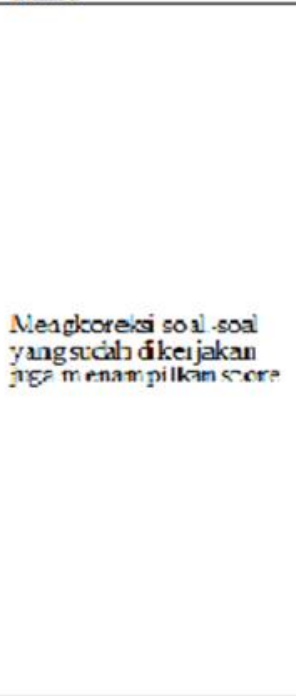 & Sesuai \\
\hline
\end{tabular}

\subsection{User Interface}

User Interface yang dihasilkan dari aplikasi yang dibangun terlihat seperti di bawah ini :

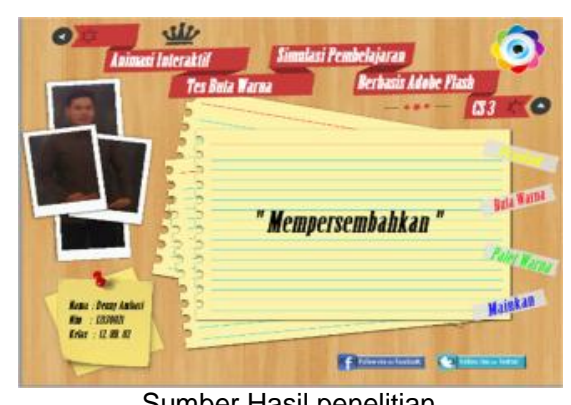

Sumber Hasil penelitian

Gambar 3.12 Halaman Utama

Pada tahap ini pengguna akan memasuki haslaman utama dari aplikasi, didalamnya terdapat tombol produk, tombol buta warna, tombol warna palet dan tomnol mainkan

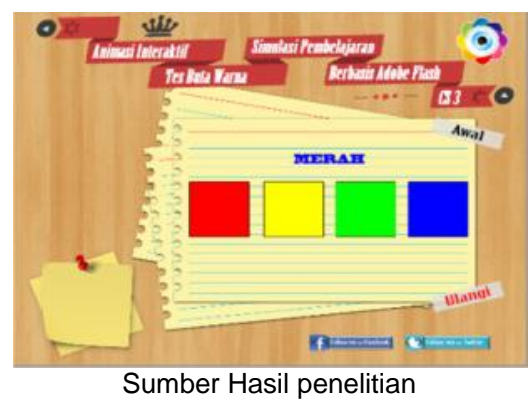

Gambar 3.13. Tebak Warna Tunggal

Pada tahap simulasi pertama, pengguna akan disuguhkan dengan soal - soal tebak warna tunggal. Peraturannya adalah dengan mencocokan perintah pilih warna pada soal da harus mencocokannya dengan palet yang tersedia. Apabila pilihan salah maka akan muncul piihan jawaban yang benar. Niali dari keseluruhan jawaban baik itu benar ataupun sebagian maka pengguna dapat masuk ke simulasi berikutnya atau ingin mengulangi kembali simulasi yang telah dimainkan. 


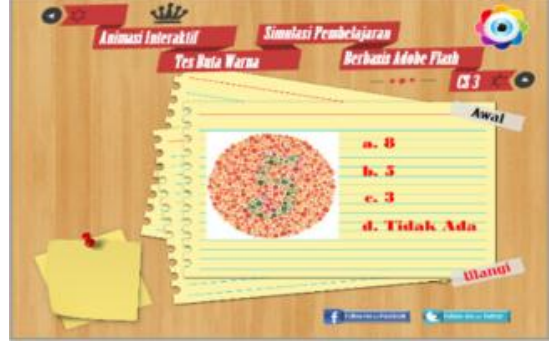

Sumber Hasil penelitian

Gambar 3.14. Tes Ishihara

Setelah simulasi pertama terselesaikan maka pengguna akan masuk kesoal - soal tes ishihara, soal - soal ini akan bersifat acak tiap kali tampil. Cukup memilih salah satu jawab yang tersedia dengan cara mengklik salah satunya. Jawaban benar ataupun salah maka soal akan terus acak dan berganti. Nilai dari keseluruhan jawaban baik itu benar ataupun sebagian maka pengguna dapat masuk ke simulsi berikutnya atau ingin mengulangi kembali simulasi yang telah dimainkan.

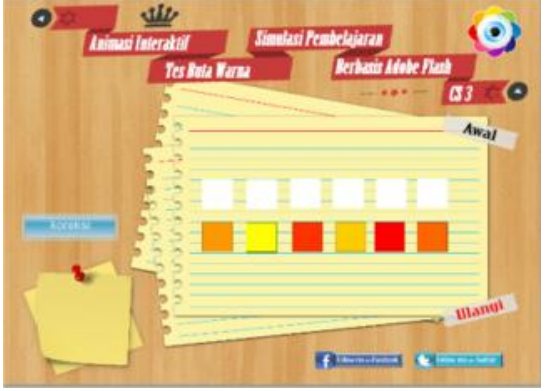

Gambar 3.15. Turunan Warna Sumber Hasil penelitian

Simulasi yang terakhir adalah turunan warna, dalam simulasi ini pengguna hanya perlumenyususn turunan warna yang sesuai dengan soal yang diberikan. Tiap soal diberi 20 detik untuk mengingat turunan warna setelah susunan warna akan teracak. Jika urutan warna benar maka akan berganti soal berikut. Dan jika salah maka soal tidak akan berganti.

\subsection{Support}

Tabel 3.2. Kebutuhan Hardware dan software

\begin{tabular}{|c|c|}
\hline Kebutuhan & Keterangan \\
\hline Sistem Operasi & Windows XP, 7 atau sesudahnya \\
\hline Processor & Intel atom 1.66 GHz atau selebihnya \\
\hline Memoi & $1024 \mathrm{MB}$ (direkomendasikan 4GB) \\
\hline Harddisk & $280 \mathrm{~GB}$ \\
\hline Sotware & $\begin{array}{l}\text { Adobe Flas'. CS 3, Adobe Phootoshop CS 3, Adobe lllustrator } \\
\text { CS 5, Formatt Factory }\end{array}$ \\
\hline
\end{tabular}

\section{Hasil Pengolahan Kuesioner}

Dalam pembuatan aplikasi dilakukan penyebaran kuesioner kepada masyarakat umum tentang aplikasi yang telah dibuat. Hasil dari olahan data dapat terlihat dibwah ini
Tabel 3.3. Kuesioner Tanggapan Pengguna

\begin{tabular}{|c|l|c|c|}
\hline \multirow{2}{*}{ No } & \multicolumn{1}{|c|}{ Pertanyaan } & \multicolumn{2}{|c|}{ Jawaban } \\
\cline { 3 - 5 } & & Ya & Tidak \\
\hline 1 & Menurut anda apakah aplikasi ini sangat mudah digunakan? & 9 & 1 \\
\hline 2 & $\begin{array}{l}\text { Apakah aplikasi ini membantu anda mengenal dan mempehjari } \\
\text { tes buta wama? }\end{array}$ & 8 & 2 \\
\hline 3 & Apakah suara dahm aplikasi terdengar sesuar? & 5 & 5 \\
\hline 4 & $\begin{array}{l}\text { Apakah gambar dan animasi pada aplikasi ni menark bagi } \\
\text { anda? }\end{array}$ & 9 & 1 \\
\hline 5 & Apakah aplikasi ini menarik untuk dipehjari? & 9 & 1 \\
\hline 6 & Menurut anda apakah soal-soal yang ada sulit untuk dijawab? & 8 & 2 \\
\hline 7 & $\begin{array}{l}\text { Apakah anda barumengetahui tentang adanya macam-macam } \\
\text { tes buta wama? }\end{array}$ & 7 & 3 \\
\hline 8 & $\begin{array}{l}\text { Menurut anda apakah perhu dikembangakan dahm bentuk tes } \\
\text { cnline via intemet? }\end{array}$ & 8 & 2 \\
\hline 9 & $\begin{array}{l}\text { Apakah pengetahuan anda bartambah setehh mencoba } \\
\text { simulasi tes buta warna? }\end{array}$ & 10 & 0 \\
\hline 10 & $\begin{array}{l}\text { Setujuhkah anda kahu aplikasi seperti ini bisa didapatkan } \\
\text { secara gratis? }\end{array}$ & 9 & 1 \\
\hline
\end{tabular}

Dengan menggunakan perhitungan :

$$
\begin{aligned}
& \frac{\text { Jumlah Jawaban }}{\text { Jumlah Soal }} \times 100 \%=\frac{82}{10} \times 100 \%=82 \% \text { Yang menjawab "Ya" } \\
& \frac{\text { Jumlah Jawaban }}{\text { Jumlah Soal }} \times 100 \%=\frac{18}{10} \times 100 \%=18 \% \text { Yang menjawab "Tidak" }
\end{aligned}
$$

Maka didapatkan sebanyak $82 \%$ responden menjawab "Ya" dan sebanyak 18\% yang menjawab tidak

Berikut ini adalah bagian dari kuesioner apliksai mengenai simulasi tes buta warna

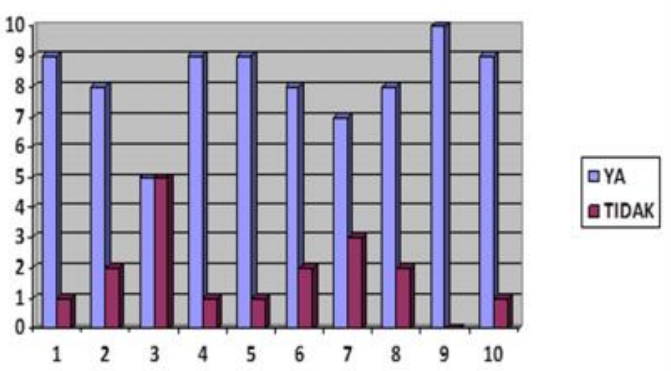

Gambar 3.16. Tampilan Gambar Grafik Kuesioner Sumber Hasil penelitian

Dapat tarik kesimpulan dari tabel dan bagan diatas bahwa masyarakat umum setuju dan tertarik dengan aplikasi mengenai simulasi tes buta warna hal ini dapat dilihat dari presentase sebanyak $82 \%$ yang menjawab 'Ya" dan sebanyak 18\% yang menjawab 'Tidak", ditambah lagi dengan bagan diagram batang yang makin memperkuat gambaran pendapat masyarakat umum yang setuju dan tertarik dengan aplikasi ini

\section{KESIMPULAN DAN SARAN}

\subsection{Kesimpulan}

Dari hasil penelitian yang telah dilakukan maka dapat ditarik kesimpulan sebagai berikut :Dengan simulasi ini dapat menarik masyarakat untuk melakukan tes buta warna, membantu pengguna untuk mengetahui macam - macam tes buta warna, walaupun hanya simulasi pengguna dibawa dalam tes yang sesungguhnya 
namun hal ini hanya bersifat simulasi saja untuk menyakinkan keakurasian tes buta warna sebaiknya tetap berkonsultasi kepada akhlinya. Selin dari kesimpulan maka peneliti memberikan saran untuk peneliti selanjutnya sebaiknya aplikasi ini dibuat dalam bentuk 3D dapat jiga dikembangkan dengan berbasis web dan juga dapat ditambahkan dengan metode metode yang lain untuk tes buta warna

\subsection{Saran}

Berdasarkan hail kesimpulan yang telah dijabarkan diatas dapat diberikan saran sebagai berikut :

1. Untuk pengembangan aplikasi yang lebih baik lagi ditambahkan dengan database, agar hasil test dapat dilihat kembali jika seaktu waktu akan dilihat kebembali

2. Untuk melakukan test kebutaan sebaiknya akan lebih baik jika berfariasi sehingga akan lebih optimal untuk menentukan kebutaan warna

3. Untuk lebih jauhnya dapat dikembangkan dengan aplikasi yang lebih up to date di masa yang akan datang.

\section{REFERENSI}

Al Fatta, Hanif, 2007, Analisa \& Perancangan Sistem Informasi, Yogyakarta, Andi

Agusta, Mulia dan Sidik 2012, Instrumen Pengujian Buta Warna Otomaatis Depok, Jurnal IImiah Elite Eletro Vol 3 No 1 Maret 2012, 15-22

Binanto, Iwan, 2010, Multimedia Digital Dasar Teori + Pengembangannya, Yogyakarta, Andi

Kurnia, Rahmat, Penetuan Tingkat Buta Warna Berbasis HIS Pada Citra Ishihara, Seminar Nasional Aplikasi Teknologi Informasi, 2009( SNATI 2009), ISSN : 19907-5022, Yogyakarta

Nugroho, Eko, 2007, Pengenalan Teori Warna, Yogyakarta, Andi
Murti, Santi,2011 Aplikasi Pendiagnosaa Kebutuhan Warna Dengan Menggunakan program Borland Delphi, ISSN:0854-9524, Semarang, Jurnal Teknologi Informasi DINAMIK Volumen 16, No 2 Juli 2011

Murti, Hari, Rina Candra Noor Santi, Aplikasipendiagnosa Kebutaan Warna dengan Menggunkan Pemrograman Borlad Delphi, Juenal Teknologi Informasi DINAMIK Volumen 16. No 2 Juli 2011: 160-170, ISSN: 085-9524

Sunyoto, Andi, 2010, Adobe Flash $+\mathrm{XML}=$ Rich Multimedia Application, Yogyakarta, Andi

Sovia, Rini, 2011, Pembuatan Aplikasi Pembelajaran Berhitung Bagi Anak Playgroup Menggunakan Metode Menghitung Gambar Dengan Menerapkan Bahasa Pemrograman Macromedia Flah 8. ISSN : 2086-4981, Medan, Jurnal Teknologi Informasi \& Pendidikan Vol 4 No. 1 September 2011.

Viyata, Dhika Randy, Ernawati, Desi Andreswari, Aplikasi Tes Buta Warna Dengan Metode Ishihara pada Smartphone Android, Jurnal Pseudocode, Volume 1, Februari 2014, ISSN 2355-5920 